\title{
PENGARUH MINAT BELAJAR DAN KEMAMPUAN BERKOMUNIKASI TERHADAP HASIL BELAJAR FIKIH SISWA MADRASAH IBTIDAIYAH NEGERI BAH KAPUL KOTA PEMATANG SIANTAR
}

\author{
Sumantri \\ Guru MIN Bah Kapul Kota Pematang Siantar
}

\begin{abstract}
This study aims to find out and to describe: (1) the effect of interest in learning on student Jurisprudence learning outcomes, (2) the effect of communication skills on student Jurisprudence learning outcomes, and (3) the influence of learning interest and the ability to communicate together on Jurisprudence learning outcomes students. This type of research is quantitative research with correlation research methods. The population of this study was all students in class V MIN Bah Kapul, Pematang Siantar City consisting of 2 classes with a total of 60 students. The instruments of data collection used were questionnaires and test results. Data analysis techniques used are correlation and regression. The research findings show: (1) a positive and significant relationship between interest in learning and student learning outcomes with a correlation number of 0.749 and a determinant coefficient of 0.561 with a regression line equation $\hat{Y}=44.72+0.50 X_{1}$ (2) a positive relationship and significant between communication skills and learning outcomes with a correlation number of 0.391 and a determinant coefficient of 0.152 with regression line equation $\hat{Y}=56.67+0.27 \mathrm{X}_{2}$ (3) a positive and significant relationship between interest in learning and the ability to communicate together with results learning with a correlation number of 0.817 and a determinant coefficient of 0.667 with the regression line equation $\hat{Y}=36.27+0.483 X_{1}+0.196 X_{2}$.
\end{abstract}

Kata Kunci: Interest in learning, communication and learning outcomes

\section{PENDAHULUAN}

Minat belajar mempunyai peranan yang sangat penting. Bila seorang siswa tidak memiliki minat dan perhatian yang besar terhadap objek yang dipelajarinya maka sulit diharapkan siswa tersebut akan tekun dan memperoleh hasil yang baik dari belajarnya. Sebaliknya, apabila belajar dengan minat dan perhatian besar terhadap objek yang dipelajari, maka hasil yang diperoleh lebih baik. Hal ini sejalan dengan penjelasan Safari (2005) bahwa minat belajar adalah pilihan kesenangan dalam melakukan kegiatan dan dapat membangkitkan gairah seseorang untuk memenuhi kesediaannya dalam belajar. 
Minat belajar yang terinternalisasi dalam diri peserta didik akan memberikan dukungan terhadap kegiatan belajar yang dilakukannya. Minat belajar merupakan satu kekuatan pada diri peserta didik dalam melakukan sesuatu tanpa tergantung orang lain tentunya mempunyai makna yang berarti bagi sseorang peserta didik dalam merencanakan, mengelola dan menyelesaikan kegiatan belajarnya. Minat belajar setiap peserta didik saling berbeda antara satu sama lainnya, hal ini dipengaruhi dari dalam dan dari luar diri peserta didik.

Selanjutnya karakteristik siswa yang dikaji dalam penelitian ini adalah kemampuan berkomunikasi. Peserta didik dengan karakteristik kemampuan berkomunikasi khsususnya komunikasi interpersonal pada umumnya adalah mereka yang mudah bergaul, aktif, optimis, bergairah, hidup, semangat, memiliki sifat empati, simpati dan persuasi yang tinggi. Sedangkan karakteristik dengan kemampuan berkomunikasi rendah memiliki ciri-ciri seperti: sulit bergaul, senang menyendiri, acuh tak acuh, pesimis, pasif, pendiam, dan sulit untuk beradaptasi dengan orang lain. Oleh karena perbedaan karakteristik kemampuan berkomunikasi diprediksikan akan memberikan pengaruh terhadap pencapaian hasil belajar Fikih peserta didik.

Materi pembelajaran Fikih berupa seperangkat pengetahuan, bentuk-bentuk ketrampilan dan penanaman sikap dan nilai dalam konteks disiplin ilmu Fikih. Di samping itu juga pembelajaran Fikih diharapkan dapat mengembangkan kemampuan berpikir yang dapat mengembangkan pengetahuan, keterampilan dan sikap percaya diri. Demikian juga dengan hasil belajar Fikih merupakan gambaran dan tingkat kesanggupan kognitif dalam bentuk pengetahuan dan ketrampilan berupa fakta, konsep, prosedur dan prinsip.

Memperhatikan karakteristik pembelajaran Fikih di atas maka faktor karakteristik kemampuan berkomunikasi turut mempengaruhi tingkat keberhasilan pencapaian keberhasilan pembelajaran Fikih. Sebagaimana penjelasan sebelumnya bahwa terdapat perbedaan karakteristik peserta didik yang mempengaruhi perkembangan kepribadian individu termasuk didalamnya adalah kemmapuan berkomunikasi. Dimana peserta didik dengan karakteristik kemampuan berkomunikasi inggi lebih berpeluang untuk menumbuhkembangkan keberhasilan belajarnya daripada peserta didik dengan karakteristik kemampuan berkomunikasi rendah. Peserta didik dengan karakteristik kemampuan berkomunikasi tinggi dalam pembelajaran Fikih menunjukkan dorongan yang kuat untuk berorientasi pada pencapaian 
prestasi belajar Fikih yang maksimal dari pada peserta didik dengan karakteristik kemampuan berkomunikasi rendah.

\section{KAJIAN TEORETIS}

Hasil belajar adalah sesuatu yang menggambarkan tingkat pencapaian belajar selama waktu tertentu. Biasanya hasil belajar didapat dari penilaian yang tidak dapat dipisahkan dari keseluruhan penyelenggaraan pendidikan (Amidjaja, 2008). Selanjutnya, Harahap (2009) menyatakan bahwa hasil belajar adalah penilaian pendidikan tentang perkembangan dan kemajuan peserta didik yang berkenaan dengan penguasaan bahan pelajaran yang disajikan kepada mereka serta nilai-nilai yang terdapat di dalam kurikulum.

Nurmawati (2016) menjelaskan hasil belajar merupakan segala prilaku yang dimiliki peserta didik sebagai akibat dari proses belajar yang ditempuhnya. Perubahan tersebut mencakup aspek tingkah laku secara menyeluruh baik aspek kognitif, afektif dan psikomotorik. Senada dengan penjelasan ini, Syah (2010) menjelaskan hasil belajar meliputi segenap ranah psikologis yang berubah sebagai akibat dari pengalaman dan proses belajar siswa baik yang berdimensi cipta, dan rasa maupun yang berdimensi karsa.

Hasil belajar adalah penilaian pendidikan tentang kemampuan peserta didikr setelah melakukan aktivitas belajar dan penilaian tentang perkembangan dan kemajuan peserta didik yang berkenaan dengan penguasaan bahan pelajaran yang disajikan kepada mereka. (Djamarah, 2004).

Berkaitan dengan hasil belajar, maka hasil belajar Fikih merupakan gambaran dan tingkat kesanggupan kognitif, pengetahuan dan ketrampilan yang diperoleh melalui proses pembelajaran. Dalam bentuk pengetahuan meliputi fakta, konsep, prosedur dan prinsip. Konsep, prosedur dan prinsip merupakan bidang kajian ilmu Fikih. Fakta, konsep, pronsip dan prosedur dalam materi ajar Fikih akan berarti atau bermakna bagi peserta didik apabila dihubungkan dengan kebutuhan peserta didik dalam kehidupan sehari-hari, sedangkan bentuk keterampilan yang menggambarkan tingkat kesanggupan kognitif, yaitu ketrampilan peserta didik menggunakan pikiran, guna menghadapi sesuatu peristiwa seperti pengambilan keputusan dan pemecahan masalah.

Winkel (2006) berpendapat bahwa minat adalah sesuatu kecenderungan jiwa yang bersifat menetap dalam diri seseorang untuk 
merasa senang dan tertarik kepada hal-hal tertentu, artinya seseorang berminat terhadap sesuatu berkaitan dengan kondisi kejiwaannya dan akan berpengaruh pada penerimaan dirinya terhadap apa yang diminati.

Sardiman (2003) mengemukakan bahwa "minat adalah suatu kondisi terjadi apabila seseorang melihat ciri-ciri atau arti sementara situasi, yang dibutuhkan dengan keinginan-keinginan atau kebutuhankebutuhannya sendiri. Menurut Crow (1988) minat adalah kemampuan untuk memberi stimuli yang mendorong siswa untuk memperhatikan seseorang, sesuatu barang atau aktivitas, atau sesuatu yang dapat memberi pengaruh terhadap pengalaman yang telah distimuli oleh kegiatan itu sendiri.

Sementara itu Khairani (2013) mengemukakan pengertian minat mewujudkan adalah: (1) minat adalah suatu gejala psikologis; (2) adanya pemusatan perhatian, perasaan dan pikiran dari subyek karena tertarik; (3) adanya perasaan senang terhadap obyek yang menjadi sasaran; dan (4) adanya kemauan atau kecenderungan pada diri subyek untuk melakukan kegiatan guna mencapai tujuan.

Menurut Muhammad (2007) komunikasi interpersonal adalah proses pertukaran informasi diantara seseorang dengan paling kurang seorang lainnya atau biasanya diantara dua orang yang dapat langsung diketahui balikannya. Komunikasi interpersonal membentuk hubungan dengan orang lain.

Abizar (1998) berpendapat bahwa komunikasi interpersonal adalah unsur amat penting dalam organisasi, sementara kemampuan untuk berkomunikasi secara interpersonal memungkinkan orang-orang mengkoordinasikan tingkah laku mereka. Ivancevic dan Matesson sebagaimana dikutip Syafaruddin dan Asrul (2007) menjelaskan bahwa komunikasi interpersonal adalah komunikasi yang mengalir dari individu kepada individu dalam tatap muka atau latar kelompok.

Devito sebagaimana dikutip Thoha (2003) menjelaskan bahwa komunikasi interpersonal akan efektif bila memenuhi aspek-aspek: (1) keterbukaan adalah aspek dari komunikasi interpersonal yang menunjukkan keinginan untuk terbuka bagi setiap orang yang berinteraksi dengan orang lain, (2) empati adalah aspek dari komunikasi interpersonal yang berkaitan dengan merasakan sebagaimana yang dirasakan oleh orang lain suatu perasaan bersama perasaan orang lain yakni mencoba merasakan dalam cara yang sama dengan perasaan orang lain, (3) dukungan adalah aspek dari komunikasi interpersonal yang berkaitan dengan pemberian dukungan yang berbentuk ucapan maupun 
gerakan, (4) kepositifan adalah aspek dari komunikasi interpersonal yang berkaitan dengan perhatian yang positif terhadap diri seseorang, dan (5) kesamaan adalah aspek dari komunikasi interpersonal yang menyatakan bahwa pada hakekatnya manusia tidak ada yang sama sekalipun kembar dapat dilihat perbedaan-perbedaannya. Oleh karena itu komunikasi interpersonal akan efektif apabila individu-individu yang berkomuniasi itu dalam suasana kesamaan.

Rakhmat (2001) menjelaskan ada tiga faktor utama yang dapat menumbuhkan sikap percaya atau mengembangkan komunikasi interpersonal yaitu: (1) menerima adalah kemampuan berhubungan dengan orang lain tanpa menilai dan tanpa berusaha mengendalikan dan juga menerima berkaitan dengan sikap melihat orang lain sebagai manusia dan sebagai individu yang patut dihargai, (2) empati adalah memahami orang lain yang tidak mempunyai arti emosional bagi kita. Dalam berempati individu menempatkan diri secara imajinatif pada posisi orang lain, dan (3) kejujuran adalah faktor yang menumbuhkan sikap percaya dalam komunikasi interpersonal

Sejalan dengan pendapat di atas, Pace dan Boren sebagaimana dikutip Muhammad (2007) bahwa komunikasi interpersonal terjalin dengan baik apabila: (1) mengembangkan suatu pertemuan personal yang langsung satu sama lain mengkomunikasikan perasaan secara langsung, (2) mengkomunikasikan suatu pemahaman empati secara tepat dengan pribadi orang lain melalui keterbukaan diri, (3) mengkomunikasikan suatu kehangatan, pemahaman yan positif mengenai orang lain dengan gaya mendengarkan dan berespons, (4) mengkomunikasikan keaslian dan penerimaan satu sama lain dengan ekspresi penerimaan verbal dan non verbal, (5) berkomunikasi dengan ramah tamah, wajar, menghargai secara positif satu sama lain melalui respons yang tidak bersifat menilai, dan (6) mengkomunikasikan satu keterbukaan dan iklim yang mendukung melalui konfrontasi yang bersifat membangun.

Berkomunikasi untuk menciptakan kesamaan arti dengan negoisiasi darti dan memberikan respons yang relevan.

\section{METODOLOGI PENELITIAN}

Penelitian dilakukan di Madrasah Ibtidaiyah Negeri Bah Kapul Kota Pematang Siantar. metode penelitian korelasi (correlational research). Populasi penelitian ini adalah seluruh siswa kelas V Madrasah Ibtidaiyah Negeri Bah Kapul Kota Pematang Siantar yang terdiri dari 2 kelas dengan jumlah 60 siswa. 


\section{HASIL PENELITIAN dan PEMBAHASAN}

Temuan penelitian ini menunjukkan bahwa terdapat hubungan positif dan signifikan antara minat belajar dengan hasil belajar siswa Madrasah Ibtidaiyah Negeri Bah Kapul Kota Pematang Siantar dengan angka korelasinya 0,749. Hal ini menunjukkan kategori hubungan antara minat belajar dengan hasil belajar siswa Madrasah Ibtidaiyah Negeri Bah Kapul Kota Pematang Siantar kategori tinggi.

Minat belajar juga memberikan sumbangan yang efektif terhadap hasil belajar dengan angkanya sebesar 55,8\%. Data ini menjadikan peluang bagi guru Madrasah Ibtidaiyah Negeri Bah Kapul Kota Pematang Siantar untuk mengaktifkan pola-pola pembinaan dan strategi pembelajaran yang lebih baik lagi agar terjadi peningkatan minat belajar yang dilakukan akan melahirkan siswa Madrasah Ibtidaiyah Negeri Bah Kapul Kota Pematang Siantar yang sukses dalam memperoleh hasil belajarnya.

Kenyataan ini merupakan fakta yang harus diperhatikan dan ditindak lanjuti oleh guru untuk melakukan konsolidasi dan pembinaan terhadap minat belajar khususnya pada aspek yang membentuk minat belajar siswa. Minat belajar yang terinternalisasi dalam diri peserta didik akan memberikan dukungan terhadap kegiatan belajar yang dilakukannya. Minat belajar merupakan satu kekuatan pada diri peserta didik dalam melakukan sesuatu tanpa tergantung orang lain tentunya mempunyai makna yang berarti bagi sseorang peserta didik dalam merencanakan, mengelola dan menyelesaikan kegiatan belajarnya.

Minat belajar setiap peserta didik saling berbeda antara satu sama lainnya. Hal ini dipengaruhi dari dalam dan dari luar diri peserta didik. Peserta didik yang mempunyai minat belajar yang tinggi akan lebih mudah memahami materi ajar Fikih dan mempraktekkannya, karena dia memiliki minat yang tinggi. Indikatornya dapat dilihat dari antusias peserta didik dalam belajar mandiri dan menemukan informasi-informasi baru dalam Fikih.

Peserta didik yang minat belajar tinggi ini akan kreatif memecahkan persoalannya sendiri dalam belajar. Hal ini tentunya berbeda pada diri peserta didik yang memiliki minat belajar yang rendah. Keinginan dan kemauannya untuk memecahkan persoalan-persoalan yang berkaitan dengan latihan-latihan pada mata kuliah Fikih tidaklah maksimal.

Melalui dan pembinaan secara intensif dan berkelanjutan sehingga minat belajar siswa Madrasah Ibtidaiyah Negeri Bah Kapul Kota 
Pematang Siantar dapat ditingkatkan pada masa mendatang, hal ini menjadi penting bgi guru dalam mempererhatikan minat belajar siswa.

Paparan di atas memberikan penjelasan dan penegasan bahwa minat belajar adalah elemen penting yang harus diperhatikan oleh kepala madrasah dalam rangka hasil belajar siswanya. Karena melalui minat belajar yang baik maka akan mendorong ketercapaian hasil belajar siswa karena proses pembelajaran yang dilakukan guru terencana dan terprogram dengan baik. Dengan demikian konsekuensinya apabila minat belajar yang kurang baik atau tidak baik sama sekali maka tentu ketercapaian hasil belajar siswa akan kurang efektif.

Kemampuan berkomunikasi juga menunjukkan hubungan positif dan signifikan dengan hasil belajar Madrasah Ibtidaiyah Negeri Bah Kapul Kota Pematang Siantar dengan besaran korelasi 0,391. Sumbangan efektif yang diberikan variabel kemampuan berkomunikasi terhadap hasil belajar sebesar 15,6\%. Data ini menjadikan peluang bagi siswa Madrasah Ibtidaiyah Negeri Bah Kapul Kota Pematang Siantar untuk mengaktifkan komunikasi yang dilakukan dengan guru, siswa lainnya maupun pihak yang ada di Madrasah Ibtidaiyah Negeri Bah Kapul Kota Pematang Siantar..

Kemampuan berkomunikasi turut mempengaruhi tingkat keberhasilan pencapaian keberhasilan pembelajaran Fikih. Sebagaimana penjelasan sebelumnya bahwa terdapat perbedaan karakteristik peserta didik yang mempengaruhi perkembangan kepribadian individu termasuk didalamnya adalah kemmapuan berkomunikasi. Dimana peserta didik dengan karakteristik kemampuan berkomunikasi inggi lebih berpeluang untuk menumbuhkembangkan keberhasilan belajarnya daripada peserta didik dengan karakteristik kemampuan berkomunikasi rendah.

Peserta didik dengan karakteristik kemampuan berkomunikasi tinggi dalam pembelajaran Fikih menunjukkan dorongan yang kuat untuk berorientasi pada pencapaian prestasi belajar Fikih yang maksimal dari pada peserta didik dengan karakteristik kemampuan berkomunikasi rendah.

Hal ini memberikan sinyal kepada kepala madrasah untuk melakukan strategi memberikan motivasi yang menarik bagi siswa sehingga guru yang ada di Madrasah Ibtidaiyah Negeri Bah Kapul Kota Pematang Siantar dapat meningkatkan teknik atau cara memberikan motivasi kepada siswa sehingga siswa dapat belajar Fikih dan menguasai materi ajar yang ada di dalamnya. Untuk itu hendaknya pembelajaran dilakukan secara komunikatif dan persuasif melalui pendekatan 
komunikasi interpersonal yang lebih intens terhadap siswa,maka diharapkan siswa termotivasi untuk belajar.

Untuk itu pemahaman guru terhadap faktor-faktor yang mempengaruhi proses dan hasil belajar mutlak diperhatikan sebagaimana tuntutan UU Nomor 20 Tahim 2003 tentang sistem pendidikan nasional yaitu tujuan pendidikan nasional adalah untuk berkembangnya potensi peserta didik agar menjadi manusia beriman dan bertaqwa kepada Tuhan Yang Maha Esa berakhlak mulia serta berilmu, cakap, kreatif, mandiri dan menjadi warga negara yang demokratis serta bertanggung jawab.

Variabel minat belajar dan kemampuan berkomunikasi secara bersama-sama menunjukkan hubungan yang positif dan signifikan dengan besaran korelasi 0,817 dan sumbangan efektif yang diberikan minat belajar dan kemampuan berkomunikasi secara bersama-sama terhadap hasil belajar Madrasah Ibtidaiyah Negeri Bah Kapul Kota Pematang Siantar adalah 71,4\%.

Hal ini bermakna bahwa masih terdapat lagi faktor-faktor yang dapat menunjang hasil belajar yang tidak dikaji dalam penelitian ini. Konsekuensi keterkaitan minat belajar dan kemampuan berkomunikasi secara bersama-sama dengan hasil belajar, maka siswa dan guru Madrasah Ibtidaiyah Negeri Bah Kapul Kota Pematang Siantar selalu melakukan komunikasi yang baik dengan siswa dan dengan pihak stakeholder lainnya.

Guru dapat meningkatkan minat belajar dan kemampuan berkomunikasi siswa Madrasah Ibtidaiyah Negeri Bah Kapul Kota Pematang Siantar juga melengkapi sarana dan prasarana yang dimiliki. Di lain pihak juga siswa selalu meningkatkan minatnya mengikuti kegiatan belajar yang serius dan sungguh-sungguh maupun dengan menambah wawasan dan pengetahuan dengan membaca buku-buku dan yang tak kalah pentingnya selalu berinteraksi dengan siswa lainnya dan guru-guru yang ada di Madrasah Ibtidaiyah Negeri Bah Kapul Kota Pematang Siantar dalam rangka meningkatkan imtaqnya.

Apabila dicermati lebih lanjut mengenai sumbangan efektif dari kedua variabel yaitu variabel minat belajar dan kemampuan berkomunikasi terhadap hasil belajar Madrasah Ibtidaiyah Negeri Bah Kapul Kota Pematang Siantar maka yang terbesar dalam memberikan sumbangan efektif adalah variabel minat belajar, hal ini disebabkan karena hasil belajar ditentukan dengan adanya faktor-faktor atau aspek yang membentuk minat belajar kondusif yaitu aspek kognitif, afektif dan psikomotorik. 
Variabel minat belajar dan kemampuan berkomunikasi secara bersama-sama menunjukkan hubungan yang positif dan signifikan dengan besaran korelasi 0,817 dan sumbangan efektif yang diberikan minat belajar dan kemampuan berkomunikasi secara bersama-sama terhadap hasil belajar Madrasah Ibtidaiyah Negeri Bah Kapul Kota Pematang Siantar adalah 71,4\%.

Hal ini bermakna bahwa masih terdapat lagi faktor-faktor yang dapat menunjang hasil belajar yang tidak dikaji dalam penelitian ini. Konsekuensi keterkaitan minat belajar dan kemampuan berkomunikasi secara bersama-sama dengan hasil belajar, maka siswa dan guru Madrasah Ibtidaiyah Negeri Bah Kapul Kota Pematang Siantar selalu melakukan komunikasi yang baik dengan siswa dan dengan pihak stakeholder lainnya.

Guru dapat meningkatkan minat belajar dan kemampuan berkomunikasi siswa Madrasah Ibtidaiyah Negeri Bah Kapul Kota Pematang Siantar juga melengkapi sarana dan prasarana yang dimiliki. Di lain pihak juga siswa selalu meningkatkan minatnya mengikuti kegiatan belajar yang serius dan sungguh-sungguh maupun dengan menambah wawasan dan pengetahuan dengan membaca buku-buku dan yang tak kalah pentingnya selalu berinteraksi dengan siswa lainnya dan guru-guru yang ada di Madrasah Ibtidaiyah Negeri Bah Kapul Kota Pematang Siantar dalam rangka meningkatkan imtaqnya.

Apabila dicermati lebih lanjut mengenai sumbangan efektif dari kedua variabel yaitu variabel minat belajar dan kemampuan berkomunikasi terhadap hasil belajar Madrasah Ibtidaiyah Negeri Bah Kapul Kota Pematang Siantar maka yang terbesar dalam memberikan sumbangan efektif adalah variabel minat belajar, hal ini disebabkan karena hasil belajar ditentukan dengan adanya faktor-faktor atau aspek yang membentuk minat belajar kondusif yaitu aspek kognitif, afektif dan psikomotorik.

\section{SIMPULAN}

Simpulan penelitian adalah: (1) terdapat pengaruh positif dan signifikan antara minat belajar siswa Madrasah Ibtidaiyah Negeri Bah Kapul Kota Pematang Siantar dengan hasil belajar Fikih. Artinya semakin tinggi dan positif minat belajar maka semakin tinggi dan positif pula peningkatan hasil belajar Fikih siswa Madrasah Ibtidaiyah Negeri Bah Kapul Kota Pematang Siantar dengan memberikan sumbangan yang efektif sebesar $55,8 \%$. Hal ini diartikan bahwa variasi yang terjadi pada 
variabel minat belajar sebesar 55,8\% dapat diprediksi dalam meningkatkan hasil belajar Fikih dengan garis prediktif $\hat{Y}=44,72+0,50 X_{1}$, (2) terdapat pengaruh positif dan signifikan antara kemampuan berkomunikasi siswa Madrasah Ibtidaiyah Negeri Bah Kapul Kota Pematang Siantar dengan peningkatan hasil belajar Fikih. Artinya semakin tinggi dan positif kemampuan berkomunikasi maka semakin tinggi dan positif pula peningkatan hasil belajar Fikih siswa Madrasah Ibtidaiyah Negeri Bah Kapul Kota Pematang Siantar dengan memberikan sumbangan yang efektif sebesar 15,6\%. Hal ini dapat diartikan bahwa variasi yang terjadi pada variabel kemampuan berkomunikasi siswa Madrasah Ibtidaiyah Negeri Bah Kapul Kota Pematang Siantar sebesar $15,6 \%$ dapat diprediksi dalam meningkatkan hasil belajar Fikih garis prediktif $\hat{Y}=56,67+0,27 X_{2}$, dan (3) terdapat pengaruh positif dan signifikan secara bersama-sama antara minat belajar dan kemampuan berkomunikasi dengan hasil belajar Fikih siswa Madrasah Ibtidaiyah Negeri Bah Kapul Kota Pematang Siantar. Artinya semakin tinggi dan positif minat belajar dan kemampuan berkomunikasi maka semakin tinggi dan positif pula hasil belajar Fikih siswa Madrasah Ibtidaiyah Negeri Bah Kapul Kota Pematang Siantar dengan memberikan sumbangan efektif sebesar $71,4 \%$. Hal ini bermakna bahwa $71,4 \%$ dari variasi yang terjadi peningkatan hasil belajar Fikih dapat diprediksi oleh variabel minat belajar dan kemampuan berkomunikasi Dengan kata lain, minat belajar dan kemampuan berkomunikasi secara bersama-sama dapat meningkatkan hasil belajar Fikih siswa Madrasah Ibtidaiyah Negeri Bah Kapul Kota Pematang Siantar dengan garis prediktif $\hat{Y}=336,27+0,483 X_{1}$ $+0,196 X_{2}$.

\section{REKOMENDASI}

Sehubungan dengan temuan penelitian ini, maka rekomendasi yang dapat disampaikan adalah: (1) kepada Kepala Madrasah Ibtidaiyah Negeri Bah Kapul Kota Pematang Siantar agar melakukan komunikasi yang intens dengan para guru dan siswa serta melengkapi sarana dan prasarana yang dimiliki serta mensupport guru untuk melaksanakan pembelajaran variatif dan menarik sehingga capaian hasil belajar pada masa mendatang dapat meningkat, (2) kepada guru Madrasah Ibtidaiyah Negeri Bah Kapul Kota Pematang Siantar agar memperhatikan peningkatan hasil belajar siswa melalui pemberian minat belajar yang kepada siswa secara variatif dan menarik dengan tentunya memperhatikan kemampuan berkomunikasi siswa, dan (3) kepada 
peneliti lain, bahwa penelitian ini perlu ditindak lanjuti khususnya yang berkaitan dengan variabel-variabel berbeda dengan penelitian ini yang turut memberikan sumbangan terhadap peningkatan hasil belajar siswa.

\section{DAFTAR PUSTAKA}

Abizar. (2007) Komunikasi Organisasi. Jakarta: Rineka Cipta.

Amidjaya, A. (2008) Pedoman Pelaksanaan Pola Pembaharuan Sistem Pendidikan dan Penilaian. Jakarta: Bumi Aksara.

Anderson, O.W. dan Krathwohl, D.R. (2001) A Taxonomy for Learning,

Teaching, and Assesing: A Revision of Bloom's Taxonomy of Educational

Objectives, New York; Longman.

Djamarah, Syaiful Bahri. dan dkk (2004). Strategi Belajar Mengajar. Jakarta: Rineka Cipta.

Khairani, Makmun. (20130 Psikologi Belajar. Yogyakarta: Aswaja Pressindo. Muhammad, Arni. (2007) Komunikasi Organisasi. Jakarta: Bumi Aksara.

Nurmawati. (2016) Evaluasi Pendidikan Islami. Bandung: Citapustaka.

Rahmat, Jalaluddin. (2001) Psikologi Komunikasi. Bandung: Remaja Rosdakarya.

Safari. (2005) Evaluasi Hasil Belajar. Yogyakarta: Pustaka Belajar.

Salim. (2018) Metodologi Penelitian Kuantitatif. Bandung:Citapustaka Media.

Siregar, (2011) Eveline dan Nara, Hartini. Teori Belajar Dan Pembelajaran.

Bogor: Ghalia Indonesia.

Slameto, (2005) Belajar dan Faktor-Faktor Yang Mempengaruhinya. Jakarta: Rineka Cipta.

Sugiyono. (2014) Metode Penelitian Kuantitatif, Kualitatif dan $R \in \mathcal{E} D$. Bandung: Alfabeta.

Syafaruddin, dan Asrul. (2007) Kepemimpinan Pendidikan Kontemporer. Bandung: Citapustaka Media.

Syah, Muhibbin. Psikologi Pendidikan Dengan Pendekatan Terbaru. Bandung: Rosdakarya, 2010.

Thoha, M. (2003) Prilaku Organisasi, Konsep Dasar Dan Aplikasi. Jakarta: Rajagrafindo Persada.

Winkel, W.S. (2006) Psikologi Pengajaran. Jakarta: Gramedia. 